\title{
MEMOIR
}

\section{ROBERT JAMES KIRTON}

ROBERT JAMES KIRTON was born on 13 July 1901. He was educated at Merchant Taylors' School and Peterhouse, Cambridge, and then joined Scottish Widows as an actuarial student. He qualified as a Fellow of the Institute in 1930 and moved in 1932 to Scottish Amicable. In 1938 he joined Equity \& Law as Assistant Manager, becoming General Manager the following year, a position which he held for 27 years. He was appointed a director of Equity \& Law in 1944 and remained on the board until 1977.

When Bob Kirton was appointed to Equity \& Law, he anticipated that there were certain problems to be tackled, but he found the situation more serious than he had thought, because of unwise expansion of new business and speculative investments, and, with the outbreak of war, it became critical. He quickly set about establishing his authority. The board was reconstituted and a new Chairman appointed and Trevor Haynes and Lewis Whyte were brought in as Actuary and Investment Manager. The triennial valuation at the end of 1940 presented difficulties, but solvency was established although there was no surplus for a bonus declaration. The office was patiently nursed through the war-years and then expanded on a sound basis. This enabled Equity \& Law, early in 1956, to be one of the first offices to declare a special bonus financed by appreciation of its equities.

Bob was a member of Council from 1942 to 1961 (with the usual one-year breaks), Honorary Secretary from 1947 to 1949 and a Vice-President from 1952 to 1955. In 1966 he was one of the first two recipients of the Silver Medal which the Institute had then recently introduced for services of special importance to the profession. The Centenary Assembly fell in the middle of his term as Honorary Secretary and he was Chairman of the Centenary Assembly Entertainments SubCommittee where his meticulous attention to detail contributed greatly to the success of the occasion. For a number of years afterwards he took a leading part in the international actuarial field and in 1950 he was elected an Extraordinary Member of the Actuarieel Genootschap in Holland. He established personal friendships with a number of American, Dutch and Norwegian actuaries.

He was the joint author with Trevor Haynes of two important papers. 'Income tax in relation to Social Security', presented to the Institute in 1943, contained proposals for simplification of income tax and its integration with social security payments. At this time, following a rapid increase in the numbers of income tax payers, the Government were considering introducing a pay-as-you-earn arrangement but had difficulty in finding a suitable system. Bob has recounted how he and Trevor Haynes, whilst waiting on the platform at Watford Junction, devised the basis which was in due course adopted-and which is still used.

Their second paper 'The financial structure of a life office' dealt with various aspects of matching and 'insulating' the office from the effects of changes in interest rates; it is a measure of the paper's value that much of what it contains is now taken for granted. It was presented to the Faculty in March 1952, one month before Frank Redington's paper 'The principles of life office valuation' was presented to the Institute. Although the approaches are different, there is much common ground between the papers and it was probably inevitable that Haynes' and Kirton's work would be overshadowed by Redington's classic.

In 1964 Bob gave a talk entitled 'The Actuary in a Modern Society' to the Actuarial Societies in Copenhagen, Oslo and Stockholm which was published in the Scandinavisk Actuarietidskrift. This shows his special interest in the recruitment and training of actuaries-he was an energetic Chairman of the Recruitment Committee from 1953 to 1956 and he particularly enjoyed his Chairmanship of the Students' Society from 1950 to 1952. After the war, Equity \& Law became a training ground for many actuaries and Bob instituted occasional dinners to which are invited all actuaries who have ever worked for the office; the number of guests is now over 150 . He became a member of the governing bodies of Bath University and the London School of Economics, where he was prevailed on to continue until he was 85 .

He also devoted much time and effort to the sick and needy. He was Chairman of the Royal United 
Kingdom Beneficent Association for 16 years and was awarded the C.B.E. in its centenary year, 1963. He took a special interest in hospital administration and became very knowledgeable on the subject. But despite all his involvement at a senior level in these and other charitable activities, he always found time to visit friends and colleagues who were sick or frail. National pensions was another matter in which he was keenly interested and it formed a major part of his work for the Life Offices' Association, of which he was Chairman from 1945 to 1947 and Chairman of the National Pensions Committee at the time the Boyd-Carpenter scheme was being introduced.

Bob was a compassionate man, with a keen sense of fun, who was much liked and respected by colleagues at all levels. He led a full and well-ordered life and enjoyed taking part in sports especially skiing, tennis and squash-all of which he continued into his 70's. He set himself the highest standards of integrity in everything he was involved in-from a major commercial transaction to a line-call in a friendly game of tennis--and he looked for the same standards in others.

Bob and his wife Susan made an excellent partnership, each supporting the other in all their interests; their happiness together was evident to all who met them. It was typical of them that, in 1986, they took a cruise to the North Cape retracing the voyage on which they had first met 60 ycars previously.

In retirement Bob liked to maintain contact with his old friends and he rarely missed a meeting of the Actuaries' Club where, before dinner, he would buttonhole members with questions or comments about what had been happening. He was in his usual good form at the February meeting of the Club, just a few days before the illness which led to his death on 7 March 1988.

M. J. Burns 